\title{
Wieżowiec One World Trade Center w Nowym Jorku - wspólczesny ekologiczny biurowiec o hybrydowej konstrukcji
}

\author{
Hanna Golasz-Szołomicka ${ }^{1}$, Jerzy Szołomicki² \\ ${ }^{1}$ Katedra Historii Architektury, Sztuki i Techniki, Wydziat Architektury, Politechnika Wroctawska \\ e-mail: hanna.golasz-szolomicka@pwr.edu.pl \\ ${ }^{2}$ Zaklad Fizyki Budowli i Komputerowych Metod Projektowania, Wydziat Budownictwa Ladowego \\ iWodnego,Politechnika Wrocławska,e-mail: jerzy.szolomicki@pwr.edu.pl
}

Streszczenie: W artykule przedstawiono elementy analizy architektonicznej i konstrukcyjnej najbezpieczniejszego ekologicznego wieżowca świata One World Trade Center, symbolu Nowego Jorku zlokalizowanego na dolnym Manhattanie. Budynek poza oczywistym symbolicznym wymiarem mówiącym o przyszłości i nadziei jest pokazem najbardziej zaawansowanych technologii. Dzięki nim projekt 1WTC przewyższa wymagania norm budowlanych Nowego Jorku i wyznacza nowe standardy dla projektowanych budynków wysokościowych. Wieżowiec ma formę ośmiościanu opartą na prostopadłościennej podstawie, przypominającą naturalny kryształ. Wraz ze wzrostem wysokości jego krawędzie są ścięte skośnie co znacząco zmniejsza oddziaływanie wiatru i stanowi główny wyznacznik przy projektowaniu wieżowców w Nowym Jorku. Artykuł przedstawia zastosowane rozwiązania projektowe z punktu widzenia innowacyjnej architektury, konstrukcji, założeń urbanistycznych, elementów bezpieczeństwa i budownictwa zrównoważonego. Zespół projektowy zastosował najnowocześniejsze metody optymalizacji wydajności energetycznej budynku, usuwania odpadów i zanieczyszczeń, oszczędzania wody, jakości powietrza i redukcję wpływu zabudowy. One World Trade Center otrzymał złoty certyfikat LEED jako budynek energooszczędny i dlatego stanowi ciekawy przypadek realizacji współczesnej myśli projektowej. Jako metodę badawczą autorzy artykułu przyjęli metodę obserwacyjną, porównawczą i krytyczną.

Słowa kluczowe: One World Trade Center; budynki wysokie; konstrukcja hybrydowa; budownictwo zrównoważone.

\section{Wprowadzenie}

Architektura jest jedną z najbardziej ekscytujących rodzajów sztuki i nic nie może się $\mathrm{z}$ nią równać, jak i z pomysłowością projektowania budynków wysokościowych. Jest to forma sztuki publicznej, którą każdy może zobaczyć i ocenić. Od połowy lat osiemdziesiątych XIX wieku wieżowce były ważnym elementem krajobrazu Stanów Zjednoczonych. Przez prawie osiem dekad budynki wysokie były w dużej mierze zjawiskiem amerykańskim, symbolizującym energię, entuzjazm i optymizm, które charakteryzowały Stany Zjednoczone pod koniec XIX i na początku XX wieku. Na początku ery wysokościowców budowle wysokie powstawały w Chicago i w Nowym Jorku, i to tam została zapoczątkowana rywalizacja o posiadanie najwyższego budynku na świecie. W 1902 roku w Nowym Jorku powstał pierwszy z wieżowców, który na zawsze zmienił obraz miasta. Flat Iron Building o wysokości $87 \mathrm{~m}$ i charakterystycznej bryle graniastosłupa o podstawie trójkąta (zwanej żelazkiem) stał się nowym symbolem rozwijającej się metropolii. W 1911 roku wybudowano 
213-metrowy budynek Metropolitan Life, który zdobył dla miasta tytuł najwyższego na świecie. W 1913 roku najwyższym budynkiem został 240-metrowy budynek Woolworth i do późnych lat 20. utrzymywał pierwsze miejsce w rankingu. Budynki te przypominały wieże gotyckich kościołów i zwane były „katedrami handlu” [1]. W tym czasie zjawisko budowania budynków wysokich podyktowane było czynnikami ekonomicznymi. Nowy Jork swój ekonomiczny sukces przypisuje w dużym stopniu wybitnym architektom i konstruktorom. Rywalizacja o najwyższy budynek przybrała na sile na przełomie lat 20-tych i 30-tych XX wieku. W ciągu jednego roku powstały trzy najwyższe wówczas na świecie wieżowce, wszystkie należące do stylu art deco. Pierwszy z nich to 282-metrowy Trump Building. Następnie w 1929 roku ukończono 319-metrowy Chrysler Building, a ukoronowaniem wyścigu o najwyższy budynek była budowa Empire State Building. Do dnia dzisiejszego jest on jednym z najbardziej charakterystycznych wieżowców Nowego Jorku. Budynek wznosi się na wysokość 381 metrów (443 metry wraz z iglicą). W chwili oddania do użytku był to najwyższy W mieście wieżowiec i jedyny na świecie posiadający więcej niż 100 pięter. To on definiował panoramę metropolii i nadawał sygnał najważniejszych stacji radiowych i telewizyjnych. Swoim statusem najwyższego budynku świata cieszył się przez ponad 40 lat, do momentu, w którym ukończono dwie wieże World Trade Center (WTC 1 - 417 metrów, WTC 2 - 415 metrów). Wówczas to one stały się centralnymi punktami nowojorskiej architektury. 11 września 2001 roku wieże zostały zniszczone w wyniku ataku terrorystycznego. W ich miejsce planowano powstanie nowego kompleksu 5 wieżowców, z najwyższym One World Trade Center.

W roku 2003 firma Lower Manhattan Development Corporation ${ }^{1}$ rozpisała konkurs na zagospodarowanie terenu dawnego kompleksu World Trade Center. Do konkursu przystąpiło siedem znanych pracowni architektonicznych: THINK Design \& Architecture, Foster\&Partners, Meier and Partners, Peterson/Littenberg, United Architects, Skidmore,Owings\&Merrill i studio Libeskind [2]. Wygrał Daniel Libeskind² i jego projekt „Fundamenty Pamięci”. Na planie zaproponowanym przez Libeskinda zaczęły powstawać budynki zaprojektowane przez różnych architektów i pracownie, Tab. 1.

Tabela 1. Wykaz pracowni architektonicznych projektujących budynki kompleksu World Trade Center [2]

\begin{tabular}{ccc}
\hline Nazwa budynku & Pracownia architektoniczna & Okres budowy \\
\hline 7 WTC & Skidmore, Owings\&Merrill & 2002-2006 \\
\hline 1 WTC & Skidmore, Owings\&Merrill & 2006-2014 \\
\hline 4 WTC & Maki and Associates & 2008-2014 \\
\hline 3 WTC & Rogers Stirk Harbour + Partners & 2010-2018 (planowany) \\
\hline 2 WTC & Foster\&Partners lub Bjarke Ingels Group & 2016-2020 (planowany) \\
\hline $\begin{array}{c}\text { Memorial Garden, National } \\
\text { Memorial Museum 9/11 }\end{array}$ & $\begin{array}{c}\text { Michael Arad } \\
\text { Peter Walker }\end{array}$ & 2006-2014 \\
\hline
\end{tabular}

LMDC - to korporacja państwowa, która została utworzona w listopadzie 2001 roku po atakach z 11 września przez ówczesnego gubernatora George’a Patakiego i burmistrza Nowego Jorku Rudolpha Giulianiego, w celu zaplanowania odbudowy Dolnego Manhattanu za pieniądze z funduszy federalnych.

2 Daniel Libeskind - amerykański architekt polskiego pochodzenia, przedstawiciel modernizmu i postmodernizmu. Do najbardziej znanych jego projektów należą: Muzeum Felixa Nussbauma (Osnabruck, 1998), Muzeum Żydowskie (San Francisco, 2008), Teatr Bord Gais Energy (Dublin, 2010), L Tower (Toronto, 2015), Apartamentowiec Złota 44 (Warszawa, 2017), Libeskind Tower (Mediolan, planowany 2019). 
Pierwotny projekt budynku One World Trade Center o nazwie Wieża Wolności należał do studia Daniela Libeskinda. Podczas projektowania zmieniała się wyraźnie forma geometryczna wieżowca (Rys. 1). W pierwszym projekcie (Rys. 1a) zaprojektowano rozczłonkowaną bryłę z wyodrębnioną smukłą wieżą. W drugim (Rys. 1b) budynek uzyskał formę jednolitej i smuklejszej bryły z wyraźnie zaakcentowaną iglicą. Mimo to projekt Libeskinda został odrzucony ze względu na zastrzeżenia Wydziału Policji Nowego Jorku dotyczące bezpieczeństwa, a w szczególności słabej wytrzymałości na obciążenie ewentualnym wybuchem. Następnie projekt wieżowca powierzono Davidowi Childsowi ze znanej i wyspecjalizowanej w budowaniu wieżowców na całym świecie pracowni architektonicznej Skidmore, Owings \& Merrill ${ }^{3}$. W pierwszej wersji (Rys. 1c) zaproponował on przekrój budynku zwężający się ku górze i od połowy wysokości ażurowy. Druga wersja (Rys. 1d) jest kompromisem projektu Childsa i propozycji Libeskinda. Ostateczny projekt budynku o nazwie One World Trade Center powstał w czerwcu 2005 roku i otrzymał przekrój prostokąta z iglicą na osi budynku (Rys. 1e).

Kamień węgielny, w postaci 20 tonowej płyty, pod 1WTC był położony w lipcu 2004 roku. Na płycie tej widnieje napis „Na cześć i ku pamięci tych którzy stracili życie 11 września 2001 r. i jako hołd dla trwałego ducha wolności”.

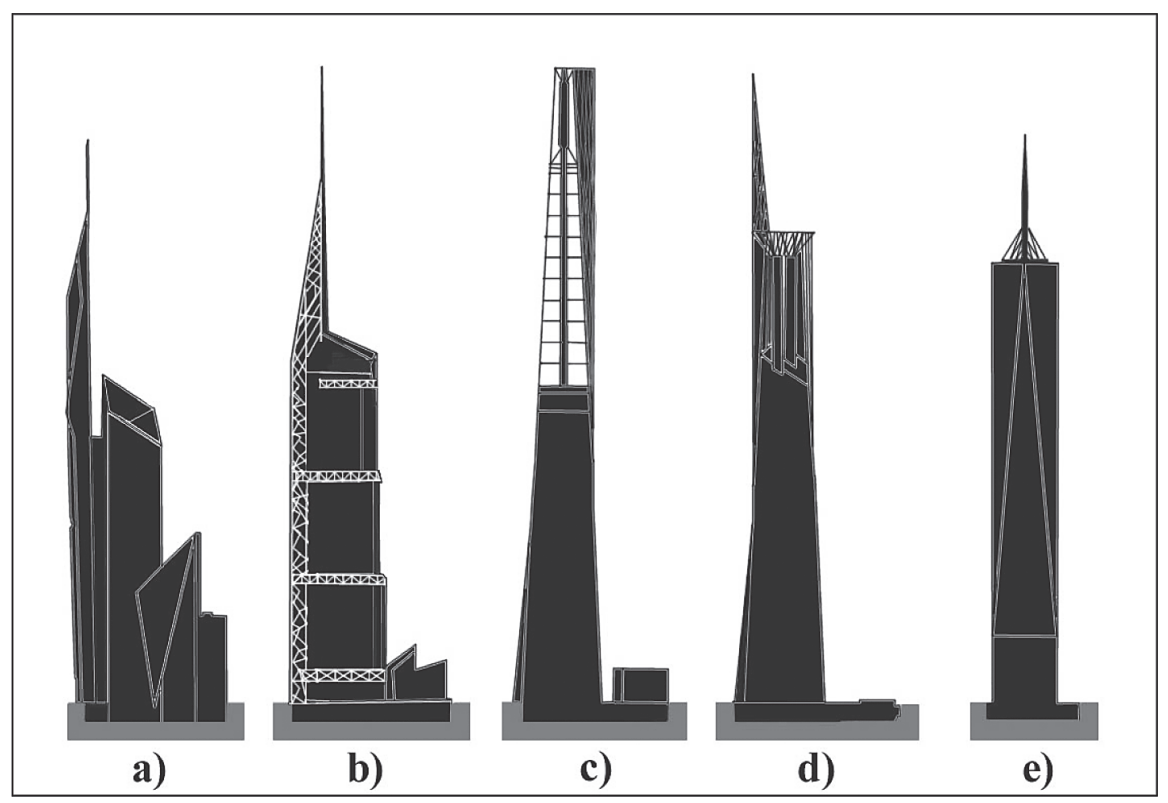

Rys. 1. Propozycje formy geometrycznej wieżowca One World Trade Center: Daniela Libeskinda (grudzień 2002), b) Daniela Libeskinda (luty 2003), c) Davida Childsa (sierpień 2003), d) wspólna propozycja Daniela Libeskinda i Davida Childsa (grudzień 2003), e) Ostateczna forma zaproponowana przez Davida Childsa (czerwiec 2005), opracowanie autorów

\footnotetext{
3 Amerykańskie biuro architektoniczne założone w Chicago w 1936 roku przez Loiusa Skidemore’a i Nathaniela Owingsa specjalizujące się w projektowaniu budynków wysokościowych. Początkowo biuro wzorowało się na realizacjach Miesa van der Rohe, by później realizować projekty w stylu postmodernizmu. Do najbardziej znanych realizacji należą: John Hancock Center (Chicago,1969), Sears Tower (Chicago, obecna nazwa Willis Tower, 1973), Jin Mao Building (Szanghaj, 1998), Burj Khalifa (Dubaj, 2010).
} 


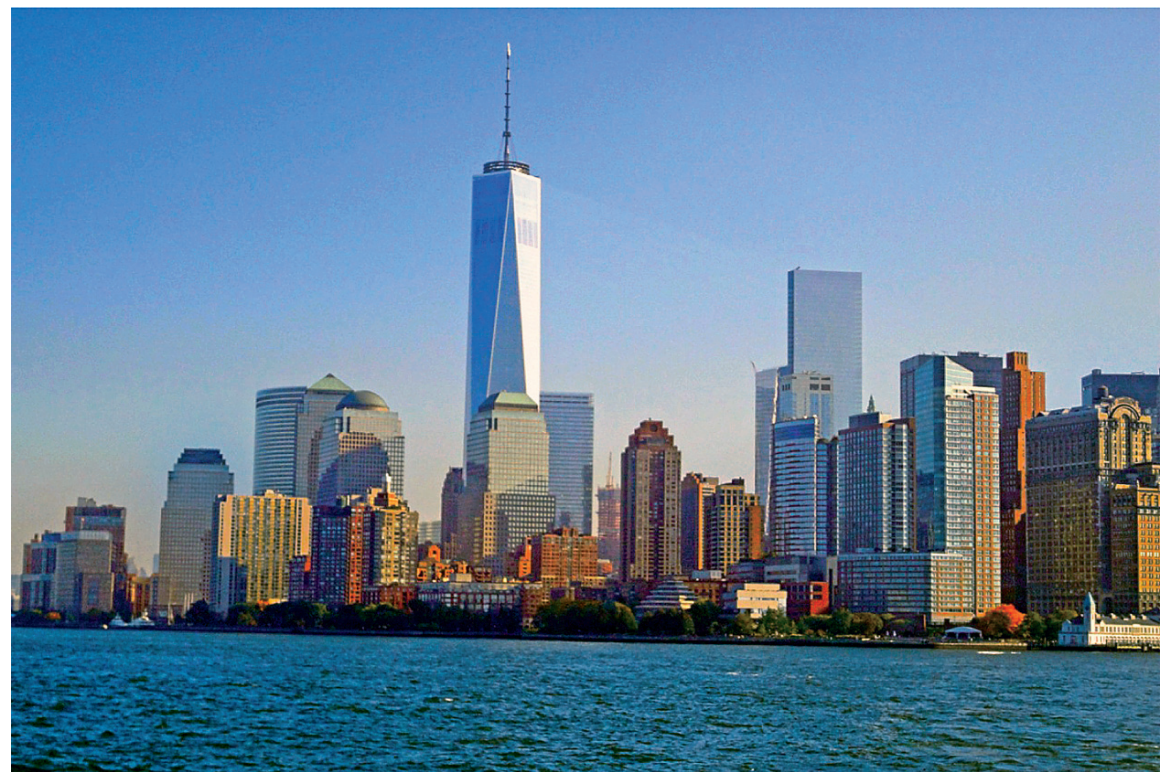

Rys. 2. Panorama dolnego Manhattanu od strony rzeki Hudson z widokiem na wieżowiec One World Trade Center, fot. wykonana przez autorów

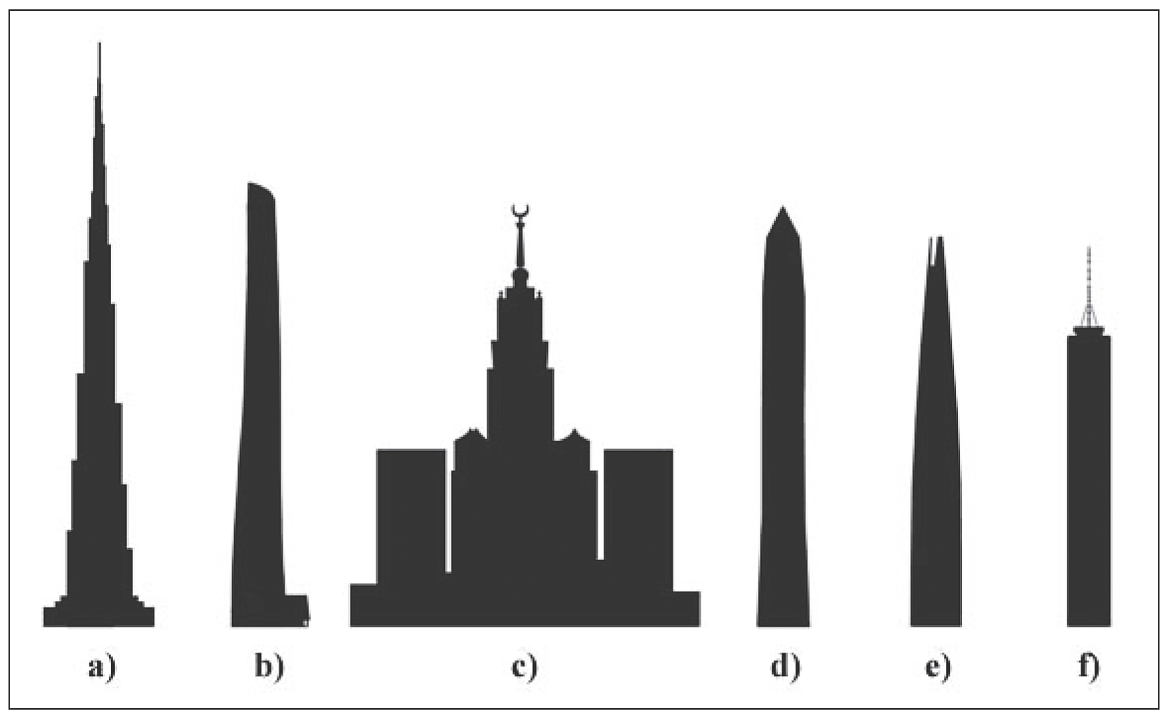

Rys. 3. Wykaz sześciu najwyższych budynków świata: a) Burj Khalifa (828 m, Dubaj,2010), b) Shanhai Tower (632 m, Szanghaj, 2015), c) Hotel Makkah Royal Clock Tower (601 m, Mekka, 2012), d) Ping An Finance Center (599 m, Shenzhen, 2017), e) Lotte World Tower (555 m, Seul, 2017), f) One World Trade Center (541 m, Nowy Jork, 2014), opracowanie autorów 


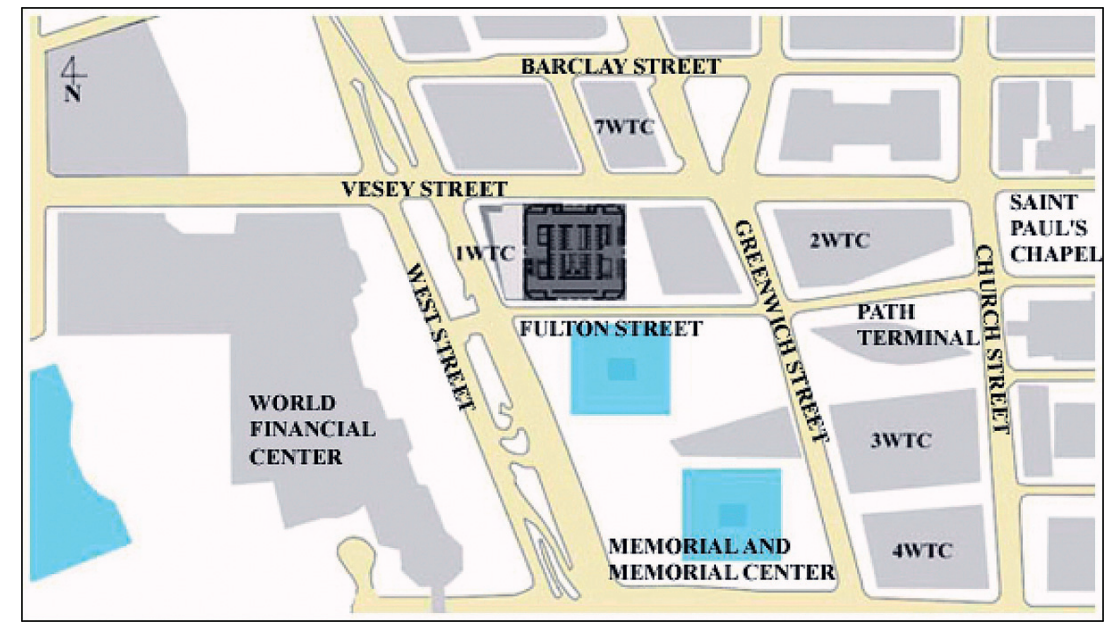

Rys. 4. Plan sytuacyjny kompleksu 5 wieżowców World Trade Center, opracowanie autorów

Budowa wieżowca rozpoczęła się w kwietniu 2006 roku, a została zakończona w listopadzie 2014 roku. Po trzynastu latach 1WTC ponownie znalazł się na widnokręgu Nowego Jorku potwierdzając dominację Manhattanu jako centrum biznesowego, stając się nową miejską ikoną Stanów Zjednoczonych (Rys. 2). Budynek ten harmonijnie wkomponowany w przylegający memoriał poza symbolicznym wymiarem jest pokazem najbardziej zaawansowanych technologii. Prostota i wyrazistość formy pozostaje świeża i ponadczasowa, przedłużając długą tradycję amerykańskiej kreatywności w budowaniu budynków wysokościowych. Rozwiązanie projektowe budynku jest innowacyjną mieszanką projektu urbanistycznego, architektury i konstrukcji, oraz rozwiązań związanych z bezpieczeństwem i budownictwem zrównoważonym.

Budynek 1WTC ma $541 \mathrm{~m}$ wysokości, co plasuje go na szóstym miejscu na liście najwyższych budynków świata (Rys. 3) i na pierwszym w Stanach Zjednoczonych. 1WTC razem z wybudowanymi 7WTC i 4WTC oraz budowanym 3WTC tworzy kompleks wieżowców (Rys. 4) o spójnej kompozycji na tle dolnego Manhattanu. Ze względu na usytuowanie obiektu w pobliżu rzeki Hudson oraz połączenie ze znajdującą się w sąsiedztwie siecią linii metra i koleją trans-Hudson ${ }^{4}$ realizacja była znacznie utrudniona.

\section{Projekt architektoniczny}

1WTC jest zlokalizowany w regionie dolnego Manhattan w bliskim otoczeniu World Financial Center, parku Battery oraz promenady West Side. Budynek stoi na północno-zachodnim narożniku 16 hektarowej działki i ograniczony jest ulicami: West na zachodzie, Vesey na północy, Fulton na południu i Washington na wschodzie. Po jego południowej stronie, w Ogrodzie Pamięci 11 Września (September 11 Memorial Garden) znajdują się dwa zagłębione w ziemi kwadratowe zbiorniki, do których spływają wodospady znaczące ślad po miejscu, w którym stały wcześniej bliźniacze wieże WTC 1 i WTC 2. Na obwodzie tych zbiorników na czarnym tle umieszczone są nazwiska wszystkich ofiar tragedii zamachu, które w ciemności fosforyzują bladym światłem. Tuż obok mieści się Narodowe Muzeum Pamięci 4 Port Authority Trans Hudson (PATH) to system metra łączącego dzielnicę Manhattan w Nowym Jorku z miejscowo-
ściami położonymi po drugiej stronie rzeki Hudson w stanie New Jersey (Jersey City, Hoboken, Harrison i Newark). 
11 Września (National 9/11 Memorial Museum), a nieopodal wybudowany kosztem blisko 4 mld dolarów dworzec Oculus zaprojektowany przez Santiago Calatrave. Z daleka konstrukcja Oculusa wygląda jak ogromny ptak z rozpostartymi skrzydłami próbujący wzbić się w powietrze. Spełnia on funkcję nowego zbiorczego węzła tranzytowego podziemnej kolei PATH.

Projekt budynku 1WTC w 2013 roku zdobył nagrodę, w corocznym konkursie Excellence in Structural Engineering, w kategorii nowy budynek powyżej 100 m. Budynek ma 104 piętra (Rys. 5), w tym 5 podziemnych z parkingiem, obiektami handlowymi i dostępem do sieci publicznego transportu. Pierwsze piętro zajmuje obszerne lobby o wysokości $15 \mathrm{~m}$, piętra 2 do 19 są przeznaczone na dolne maszynownie, 20-88 zajmują biura ${ }^{5}$, 89-99 i 103-104 są przeznaczone na górne maszynownie. Na piętrach 100 do 102 znajduje się taras widokowy. Wysokość dachu jest taka sama jak pierwotnie w WTC 1 (417 metrów). W budynku znajdują się 73 windy (10 kursujących poprzez wszystkie kondygnacje budynku), w tym 54 szybkobieżne pasażerskie i 11 schodów ruchomych. Wieżowiec wznosi się na wysokość 1776 stóp (541 metrów) co nawiązuje do roku ogłoszenia amerykańskiej deklaracji niepodległości. Budynek jest zwieńczony 124 metrową iglicą. Wierzchołek iglicy jest uważany jako architektoniczny szczyt budynku (podobnie jak w innych nowo powstałych wieżowcach). W pierścieniu iglicy znajdują się anteny służące jako narzędzie nadawcze do transmisji radiowej i telewizyjnej. W pobliżu jej wierzchołka znajdują się lampy ksenonowe, które wysyłają poziomą wiązkę światła i tworzą literę N w alfabecie Morse'a. Pomysł ten zrodził się z chęci stworzenia latarni przypominającej kod świetlny sprzed stuleci dla wpływających statków, żeby zidentyfikować ich port. Jest to symboliczne działanie, gdzie latarnia przypomina morską przeszłość Nowego Jorku i promuje bezpieczne powitanie w porcie.

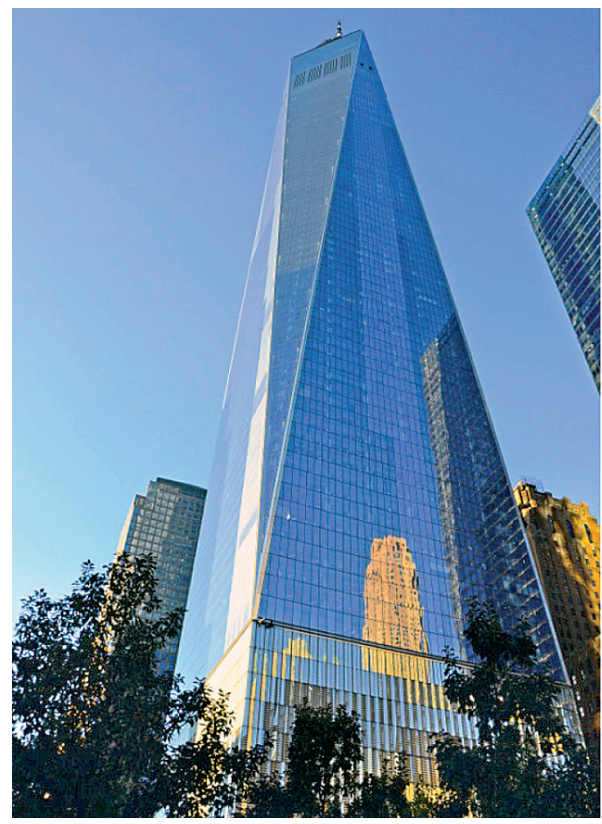

Rys. 5. Fasada budynku 1WTC, fot. wykonana przez autorów

\footnotetext{
5 biura na piętrach 20-88 (koncern wydawniczy Conde Nast (czasopisma „Vogue”, „The New Yorker” i „Vanity Fair"), U.S. General Service Administration, Global Digital Gaming Company High 5, firma reklamowa Tech xAd, Moody Bank, chińska firma handlu nieruchomościami Beijing Vantone Industrial Company).
} 


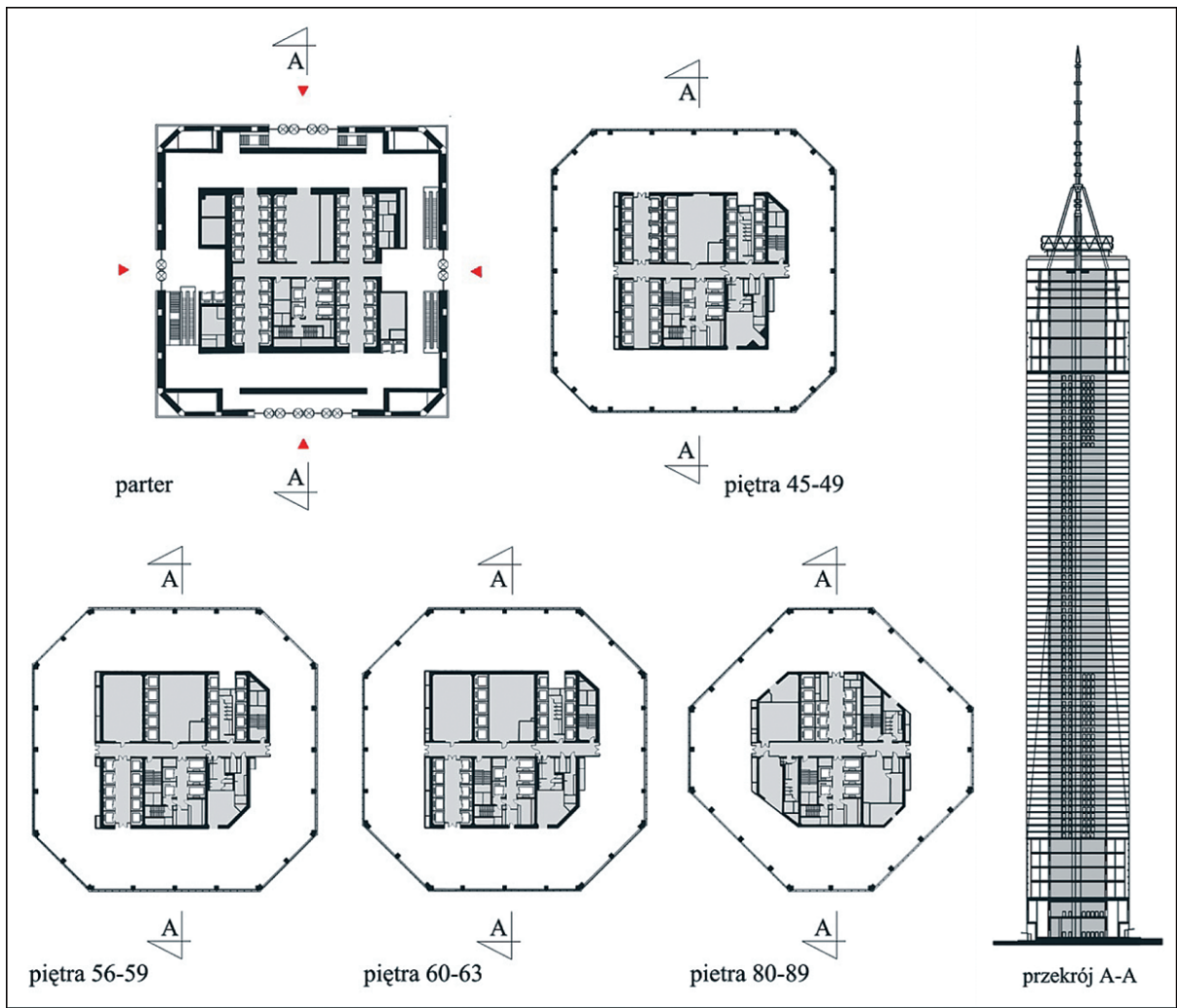

Rys. 6. Przekrój i rzuty 1WTC na różnych poziomach wieżowca, opracowanie autorów na podstawie $[3,4]$

Wieżowiec 1World Trade Center ma bryłę prostopadłościanu ze ściętymi narożnikami opartą na prostopadłościennej podstawie. Wraz ze wzrostem wysokości budynku od poziomu podstawy, jego krawędzie tworzą formę geometryczną złożoną z ośmiu wydłużonych równoramiennych trójkątów (cztery w górę i cztery w dół, na przemian, Rys. 7). W środkowej części powstaje idealny ośmiokąt w rzucie. Następnie jest on zwieńczony szklaną attyką, która w rzucie ma kształt kwadratu o wymiarze $45 \mathrm{~m}$ i jest obrócona o kąt 45 stopni w stosunku do podstawy. Forma budynku nawiązuje do kształtu kryształu i podobnie jak on załamuje promienie słoneczne. Wraz z ruchem słońca i zmianą warunków pogodowych elewacje zmieniają kolor.

Podstawę wieżowca zaprojektowano na planie kwadratu $(61 \mathrm{~m})$, natomiast konstrukcja stanowi kwadrat ze ściętymi narożnikami. W centralnej części umieszczono żelbetowy trzon na planie kwadratu $(33,5 \mathrm{~m}) \mathrm{w}$ którym umieszczono klatki schodowe i windy. Żelbetowa podstawa ma wysokość 19 kondygnacji. Od 20 kondygnacji rzuty poszczególnych pięter i przekroje trzonu zmieniają się wraz z kształtem bryły (Rys. 6).

Do budynku prowadzą cztery wejścia, spośród których zachodnie jest przeznaczone dla turystów, a pozostałe dla pracowników biurowca (Rys. 7). Najbardziej reprezentacyjne jest wejście południowe połączone z lobby i związane z Ogrodem Pamięci 11 września. Na osi każdej ze ścian umieszczono wysoką prostokątną niszę, w której w dolnej części zaprojektowano drzwi, wyżej pas okien i daszek wykonany z laminowanego szkła oparty na stalowych 
profilach o zmiennym przekroju. Ponad strefą wejściową znajdują się wysokie pionowe szyby w fasadzie mocowanej punktowo. Prostokątne nisze w elewacji akcentują strefę wejściową, ale również stanowią główne oświetlenie podstawy wieży. Fasadę podstawy stanowi stalowa ściana kurtynowa o podziałach poziomych, za którą umieszczono wentylację dla kondygnacji przeznaczonych na maszynownie. Tworzy ona poziome pasy jasne i ciemne (zacienione), na które nałożono pionowe tafle szyb.

Elewacja podstawy wieżowca zmienia się od gładkiej poprzez ażurową do ponownie gładkiej. Połączenie stalowej i szklanej powłoki załamuje i transmituje światło tworząc dynamiczną i falującą fasadę. W przyziemiu znajduje się kamienny cokół, a nad nim pas okien, który odpowiada wysokości obrotowych drzwi wejściowych. Powyżej zastosowano wysokie szklane tafle połączone w pary stalowym profilem z nierdzewnej stali o ruchomych skrzydłach. Są one ustawione od różnym kątem w stosunku do pionowej osi tworząc regularny wzór na całej wysokości betonowej podstawy (Rys. 8). Zastosowano ponad 4000 sztuk potrójnie laminowanego szkła o wymiarach 3,9 m x 0,6 m. Kąt między ruchomymi skrzydłami zmienia się od najbardziej rozwartego kąta w dolnej części fasady do kąta ostrego w połowie wysokości i ponownie rozszerza się do górnej granicy.

Podstawę wieńczy wąski, poziomy gzyms ponad którym zastosowano gładką, szklaną fasadę segmentową o podziałach pionowych. Bazuje ona na panelach o wymiarach 1,52 m x 4,06, których wysokość jest równa wysokości pojedynczej kondygnacji. W fasadzie zastosowano potrójnie laminowane szyby firmy Viracon ${ }^{6}$ [5], których wysoko wydajna powłoka zmniejsza ilość przenikającego ciepła, promieniowania UV i podczerwieni, przy zachowaniu maksymalnej przepuszczalności światła widzialnego. Szerokości okien odpowiadają podziałom pionowym w przyziemiu. Panele na 20 piętrze są najcięższe ze względu na wymagania dotyczące odporności na obciążenie wybuchem.

Narożniki ściętych boków zaakcentowano ramą o trójkątnym profilu dzięki czemu ściany są lekko cofnięte w stosunku do ścian wychodzących z podstawy. W górnej ich części umieszczono wysokie, pionowe otwory wentylacyjne, które tworzą w fasadzie zacienione, pionowe pasy. Elewację wieńczy szklana balustrada. W elewacji wieżowca podkreślono podziały pionowe. Przyziemie sprawia wrażenie masywnej, dynamicznej podstawy oddzielonej poziomym gzymsem od gładkiej, spokojnej, szklanej fasady. Ściana osłonowa daje maksymalną ilość światła dziennego oraz podkreśla monumentalność budynku.
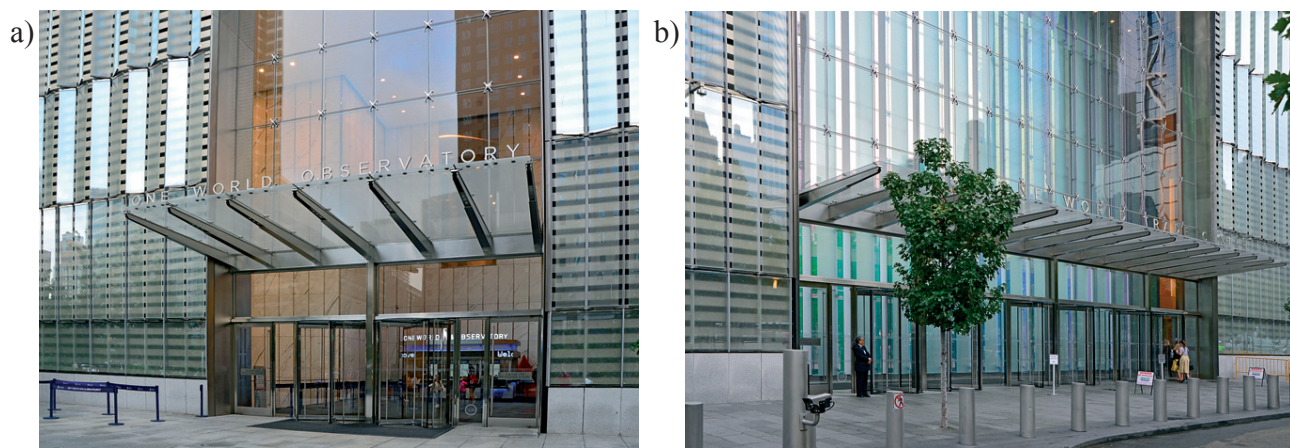

Rys. 7. Wejścia do budynku 1WTC: a) od strony zachodniej, b) od strony południowej, fot. wykonana przez autorów

\footnotetext{
6 Viracon - amerykańska firma powstała w 1970 roku w Owatonn w stanie Minesota specjalizująca się w produkcji szkła architektonicznego w budynkach wysokościowych.
} 
a)
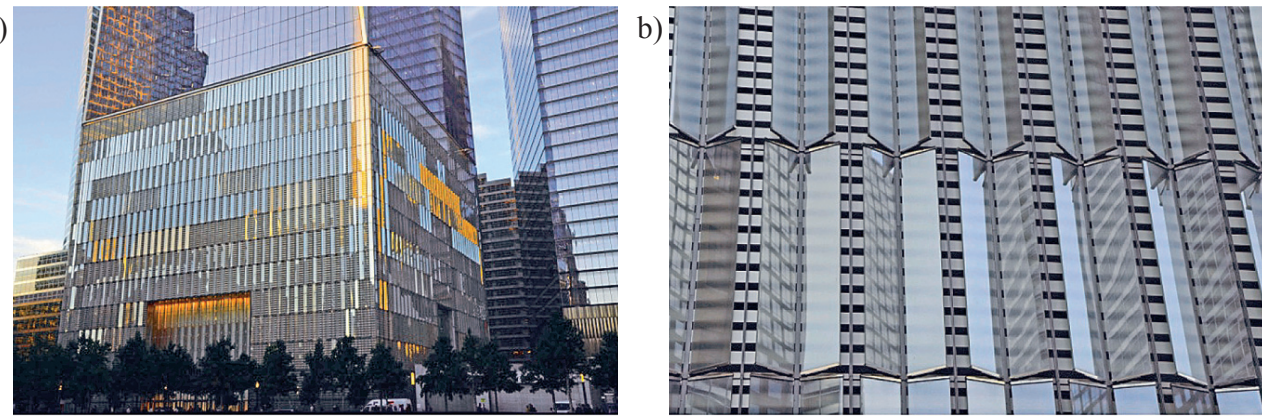

Rys. 8. Prostopadłościenna żelbetowa podstawa budynku 1 WTC pokryta potrójnie laminowanym szkłem: a) widok podstawy, b) elementy pokrycia żelbetowej podstawy położone pod różnym kątem w stosunku do pionowej osi tworzące nieregularny wzór, fot. wykonana przez autorów

\section{Projekt konstrukcyjny}

Projekt konstrukcji budynku łączy w sobie najbardziej zaawansowany system bezpieczeństwa, który przewyższa wymagania norm budowlanych Nowego Jorku i wyznacza nowe standardy dla budynków wysokościowych. Od samego początku jednym z głównych wyzwań przy projektowaniu konstrukcji był odpowiedni wybór norm projektowych. Na początku przyjęto najnowszą wersję norm budowlanych Nowego Jorku z roku 1968 z pewnymi poprawkami w połączeniu z wytycznymi projektowymi władz Portu Nowego Jorku i New Jersey. Jednak biorąc pod uwagę, że konieczne było zaprojektowanie tego budynku przy użyciu najbardziej zaawansowanych technologii dostępnych w tym czasie, przyjęto jako główną normę International Building Code 2003, szczególnie w odniesieniu do obciążeń wiatrem i obciążeń sejsmicznych. Ponadto zastosowano normy Amerykańskiego Instytutu Konstrukcji Stalowych (AISC) i normy Amerykańskiego Instytutu Konstrukcji Betonowych (ACI) $[6]$.

Wieżowiec One World Trade Center został posadowiony w granitowej skale z wykorzystaniem pasmowych ław i stóp fundamentowych o nośności 6 ton na metr kwadratowy. Ze względu na ograniczenia przestrzenne, spowodowane bliskością istniejących linii kolejowych, konieczne było większe zagłębienie w celu uzyskania większej nośności. Zakotwienie fundamentu w skale sięgało głębokości 24 m, aby przeciwstawić się efektowi momentu wywracającego w wyniku działania ekstremalnego wiatru?

Konstrukcja wieżowca składa się z systemu hybrydowego [3,4] łączącego masywny żelbetowy trzon z obwodową stalową ramą (Rys. 9). Istotnym elementem konstrukcji jest dziewiętnasto kondygnacyjna żelbetowa podstawa, której masywne żelbetowe ściany służą jako ukryta bariera bezpieczeństwa. W konstrukcji występują zewnętrzne stalowe i żelbetowe słupy o przekroju prostokątnym, które zapewniają możliwość swobodnego kształtowania przestrzeni. Ponadto w części przeznaczonej dla zwiedzających stropy dodatkowo podparto żelbetowymi słupami o przekroju kołowym (Rys. 10).

\footnotetext{
W Nowym Jorku największy wpływ na konstrukcję wieżowców ma oddziaływanie wiatru. Dlatego na etapie projektowania przeprowadzono w tunelu aerodynamicznym Rowan Williams Davies i Irwin Inc. w Kanadzie testy modelowe wysokiej częstotliwości i aeroelastyczne [7]. Geometryczny kształt One World Trade Center, o bryle zwężającej się wraz z wysokością, w połączeniu ze ściętymi narożnikami efektywnie redukuje oddziaływanie wiatru.
} 


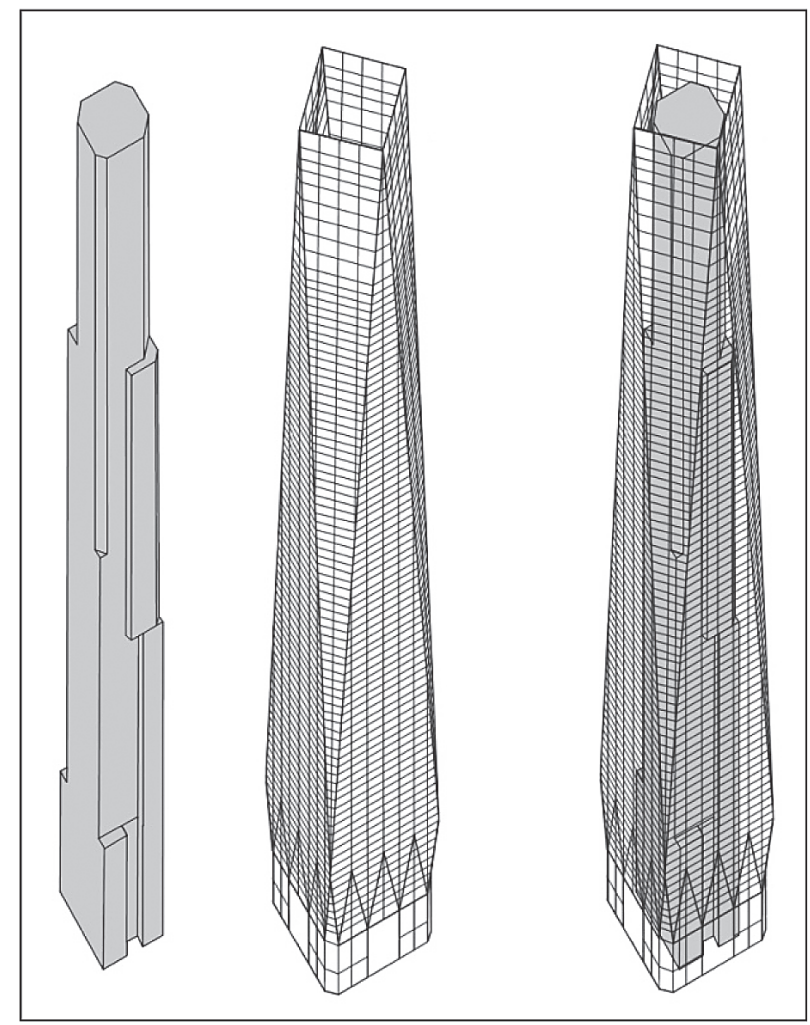

Rys. 9. Konstrukcja hybrydowa budynku 1WTC składająca się z żelbetowego trzonu i stalowej ramy, opracowanie autorów

Żelbetowy trzon ścienny w środku budynku jest głównym elementem nośnym, który przenosi obciążenia grawitacyjne oraz przeciwdziała obciążeniom poziomym od wiatru i oddziaływaniom sejsmicznym. Ze względu na jego bardzo dużą sztywność nie było potrzeby wprowadzenia specjalnego tłumika drgań ${ }^{8}$. Trzon ma rzut kwadratowy o długości w podstawie 33,5 m, co jest wystarczające żeby stanowić samodzielny budynek.

Układ trzonu w planie budynku ma kluczowe znaczenie dla efektywności biurowca, poza oczywistymi względami konstrukcyjnymi. Trzony budynków mogą być rozmieszczone na kilka sposobów. Centralne zintegrowanie trzonów z zewnętrzną konstrukcją umożliwia jednakowy obwód światła i widok, wpływając na wydajne miejsce pracy. Budynki z trzonami usytuowanymi z boku mają tę zaletę, że mają jednorodne miejsca pracy, zwykle zorganizowane w jedną przestrzeń. Ten rodzaj budynku biurowego do niedawna był standardem w Japonii i Korei.

W zależności od konstrukcji budynku i jego formy geometrycznej w budynkach wysokich występują różne kształty trzonów: na planie wieloboku, kwadratu, krzyża, trójnogu oraz mogą występować trzony podwójne (Rys. 11). W celu osiągnięcia maksymalnej

\footnotetext{
8 Tłumiki drgań są stosowane w budynkach wysokich w celu redukcji drgań wywołanych oddziaływaniami wiatru, sejsmicznymi i parasejsmicznymi. Współcześnie stosuje się aktywne, quasi-aktywne oraz hybrydowe układy tłumiące, które stanowią naturalne rozwinięcie układów pasywnych w formie izolatorów drgań fundamentów czy układów rozpraszających energie.
} 
efektywności przestrzennej ${ }^{9}$ wieżowca biurowego, powierzchnia trzonu musi być zredukowana do akceptowalnej proporcji powierzchni brutto kondygnacji. Przy analizie 12 wybranych najwyższych budynków biurowych świata, stwierdzono że powszechnie występują trzony pojedyncze i centralnie położone. Tylko wieżowiec Bank of China w Hong Kongu ma podwójny trzon, którego wymiary zmniejszają się wraz z wysokością. Stosunek powierzchni trzonu do powierzchni użytkowej brutto zmienia się między $22 \%$ a $30 \%$ przy średnim stosunku 26\% (Tab. 2).

W trzonie wieżowca One World Trade Center znajdują się pomieszczenia mechaniczne i komunikacyjne. Jego konstrukcja jest podzielona na sekcje dodatkowymi ścianami w kierunkach prostopadłych. Wylewane na miejscu budowy żelbetowe ściany trzonu mają zmienną grubość w zależności od wysokości budynku, które wynoszą: 1,80 m poniżej poziomu gruntu i około $90 \mathrm{~cm}$ wokół trzonu budynku powyżej poziomu terenu. Prostopadłościenna żelbetowa podstawa budynku dochodząca do 19 kondygnacji ma masywne ściany, które są odporne na obciążenie wybuchem.

Tabela 2 Charakterystyka trzonów w wybranych wieżowcach na świecie, opracowanie autorów na podstawie [8]

\begin{tabular}{cccc}
\hline Nazwa budynku & $\begin{array}{c}\text { Liczba } \\
\text { trzonów }\end{array}$ & $\begin{array}{c}\text { Powierzchnia } \\
\text { trzonu }\left(\mathrm{m}^{2}\right)\end{array}$ & $\begin{array}{c}\text { powierzchnia trzonu/powierchni } \\
\text { kondygnacji (\%) }\end{array}$ \\
\hline One World Trade Center & 1 & 1122 & 30 \\
\hline Lotte World Tower & 1 & 1280 & 25 \\
\hline Taipei 101 Tower & 1 & 665 & 25 \\
\hline Shanghai World Financial Center & 1 & 750 & 30 \\
\hline Petronas Twin Towers 1-2 & 1 & 530 & 25 \\
\hline Willis Tower & 1 & 1113 & 22 \\
\hline Jin Mao Tower & 1 & 800 & 26 \\
\hline Two International Finance Center & 1 & 740 & 22 \\
\hline Citic Plaza & 1 & 480 & 26 \\
\hline Shun Hing Square & 1 & 570 & 25 \\
\hline Central Plaza & 1 & 560 & 30 \\
\hline Bank of China & 2 & 800 &
\end{tabular}

System stropowy wewnątrz strefy trzonu składa się z wylewanych na miejscu betonowych belek i systemu płyt stropowych. System bez słupowy rozciąga się pomiędzy trzonem i obwodową stalową ramą. Stropy na 2 i 90 piętrze mają większą grubość ze względu na zwiększone obciążenie użytkowe. Strop na zewnątrz trzonu jest stropem kompozytowym opartym na stalowych belkach połączonych poprzez ścinane łączniki.

Wytrzymałość betonu dla fundamentów, słupów i ścian trzonu jest w zakresie 55-95 MPa, a dla żelbetowych płyt stropowych przyjmuje wartości od 28-60 MPa.

9 Efektywność przestrzenną wysokiego budynku można osiągnąć poprzez maksymalizację powierzchni brutto (GFA) i powierzchni użytkowej netto (NFA). Efektywność tą można zdefiniować jako stosunek NFA do GFA. 


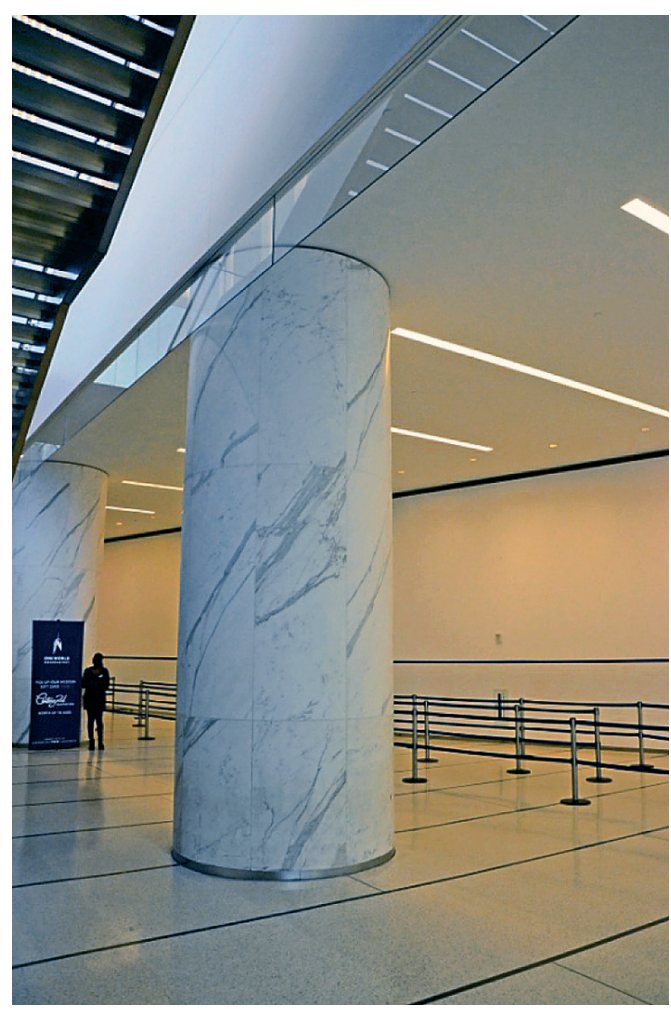

Rys. 10. Żelbetowy słup nośny w zewnętrznej części budynku na poziomie pierwszej kondygnacji poniżej lobby, fot. wykonana przez autorów

Zwieńczenie budynku stanowi stalowa iglica o wysokości $124 \mathrm{~m}$. Jest to konstrukcja hybrydowa składająca się z dwóch głównych elementów: masztu i trójpoziomowego pierścienia platformy komunikacyjnej (Rys. 12). U podstawy masztu znajduje się okrągły pierścień kratowy, do którego zamocowano anteny sterowane elektronicznie [9]. Aby przeciwdziałać oddziaływaniu wiatru, do pierścienia zamocowano 8 masywnych kabli Kevlara ${ }^{10}$. Maszt stalowy składa się z ośmiu sekcji ułożonych pionowo w stos i o zmniejszających się szerokościach. Początkowo projekt iglicy zawierał okładzinę, jednak nie spełniła ona wymagań testów w tunelu aerodynamicznym. Wyposażenie do mycia okien zostało włączone do struktury pierścienia. Ze względu na okrągły kształt pierścienia, budynek można obsługiwać tylko trzema jednostkami konserwacyjnymi. Konstrukcja pierścienia i masztu została stworzona we współpracy z inżynierami budowlanymi ze Stuttgartu, firmy Schlaich Bergermann\&Partner ${ }^{11}$.

\footnotetext{
${ }^{10}$ Kevlar jest polimerem z grupy aramidów z którego tworzy się włókna sztuczne o wysokiej wytrzymałości na rozciąganie. Ze względu na swoją wytrzymałość stosowany jest również jako zbrojenie kompozytów o osnowie polimerowej.

11 Schlaich Bergermann\&Partner - firma konstrukcyjno-budowlana z siedzibą w Stuttgarcie (Niemcy) założona w 1980 roku przez Jörga Schlaicha i Rudolfa Bergermanna. Do najbardziej znanych zrealizowanych projektów w których firma uczestniczyła należą: dworzec Berlin Hauptnahnhof, stadion Narodowy w Warszawie, iglica w wieżowcu One World Trade Center (Nowy Jork).
} 


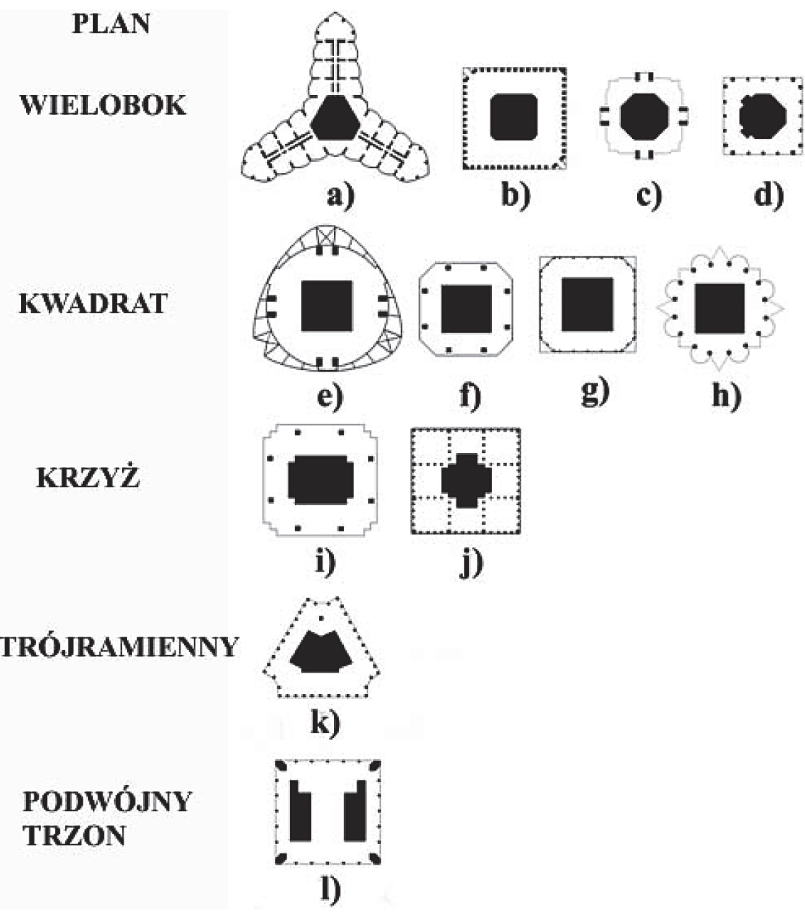

Rys. 11. Rzuty trzonów w wybranych wysokościowych budynkach biurowych, opracowanie autorów na podstawie [8]: Burj Khalifa (Dubaj), b) Shanghai World Financial Center (Szanghaj), c) Jin Mao Tower (Szanghaj), d) CITIC Plaza (Guanhgzhou), e) Shanghai Tower (Szanghaj), f) Lotte World Tower (Seul), g) One World Trade Center (Nowy Jork), h) Petronas Tower 1 i 2 (Kuala Lumpur), i) Taipei 101 (Tajpej), j) Willis Tower (Chicago), k) Bank of China Tower (Hong Kong), 1) Central Plaza (Hong Kong)

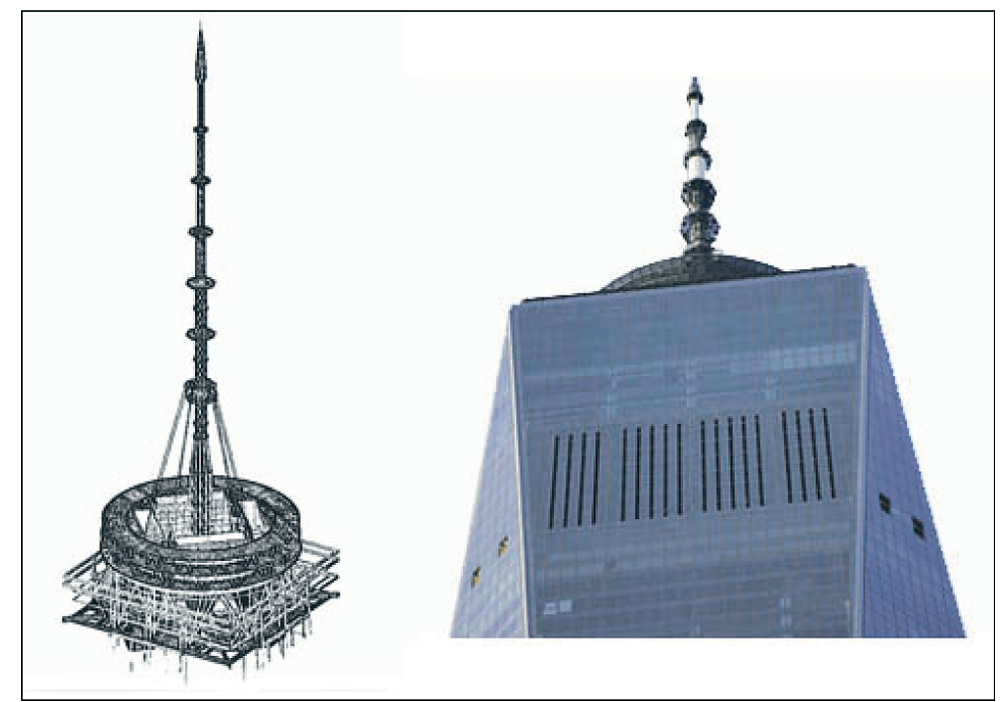

Rys. 12. Konstrukcja hybrydowa stalowej iglicy stanowiącej zwieńczenie budynku 1WTC, opracowanie autorów 


\section{Charakterystyka betonu o wysokiej wytrzymałości}

W trzonach wieżowców do końca lat 90-tych stosowano beton o wysokiej wytrzymałości, który miał wytrzymałość na ściskanie w zakresie 55 do $70 \mathrm{MPa}$. W trakcie realizacji projektu wieżowca Trump World Tower w Nowym Jorku, po raz pierwszy w historii USA uzyskano beton o wytrzymałości $80 \mathrm{MPa}$. Inżynierowie opracowali także beton o jeszcze większej wytrzymałości w zakresie $80-100 \mathrm{MPa}$ i module Younga ${ }^{12} 48 \mathrm{GPa}$. Na początku 2010 roku taki beton był wykonywany dla budynku 1WTC, Tab. 3. Wyzwaniem w betonowaniu było wpompowanie tej wysoko wytrzymałej mieszanki betonowej na wysokość 104 kondygnacji. Pompowanie betonu odbywało się za pomocą pojedynczej pompy bezpośrednio z poziomu gruntu na wyższe kondygnacje. Nie było potrzeby zastosowania pośredniej stacji w celu ponownego wymieszania mieszanki betonowej i skierowanie jej do drugiej pompy, co było wcześniej często praktykowane. Kluczowym czynnikiem zapewniającym sukces w tak wymagających mieszankach betonowych była kontrola jakości i ścisłe monitorowanie składników mieszanki, a także stosowanie lokalnych materiałów, które były łatwo dostępne. Do kontroli jakości układania mieszanki betonowej wykorzystano rejestratory danych z funkcją identyfikacji radiowej (RFID), które zostały osadzone w betonie, aby zmierzyć wewnętrzną temperaturę betonu, ciepło hydratacji i dojrzewania betonu w monolitycznych ścianach konstrukcyjnych. Ułatwiało to odpowiednio wczesne usuwanie deskowania i pomagało skrócić cykl budowy.

Beton o wysokiej wytrzymałości stosowany do grubych ścian betonowych trzonu, określany jako beton masowy, wymagał odpowiedniej mieszanki betonowej, aby spełnić stawiane mu wymagania. Osiągnięcie celu było możliwe poprzez ograniczenie zawartości cementu portlandzkiego w mieszankach i przesunięcie harmonogramów układania mieszanki betonowej w chłodniejszych porach dnia i w nocy. Dzięki temu uniknięto nadmiernego ciepła hydratacji i podczas procesu utwardzania opóźnienie formacji ettringitowej [10]. Wszystkie mieszanki, w zależności od potrzeb, zawierały dodatkowe materiały cementowe, popiół lotny, granulowany zmielony cement żużlowy wielkopiecowy i pył krzemionkowy. Z powodu dużej wysokości i smukłości konstrukcji budynku, proporcje mieszanki betonowej dla trzonu zostały zaprojektowane z uwzględnieniem pełzania, skurczu i modułu sprężystości. Szczególnie zwrócono uwagę na gruboziarnisty agregat (kruszywo ze skał granitowych), w celu uzyskania modułu sprężystości przekraczającego $45 \mathrm{GPa}$.

Tabela 3 Zestawienie wytrzymałości betonu na ściskanie w wybranych wieżowcach [11]

\begin{tabular}{ccc}
\hline Nazwa budynku & $\begin{array}{c}\text { Maksymalna wytrzymałość } \\
\text { beton (MPa) }\end{array}$ & Zastosowanie \\
\hline One World Trade Center & 96,5 & ściany trzonu \\
\hline Taipei 101 & 68,9 & wypełnienie stalowych słupów \\
\hline Burj Khalifa & 80 & ściany do poziomu 126 kondygnacji \\
\hline Petronas Twin Towers & 80 & słupy i trzon do poziomu 23 kondygnacji \\
\hline Shanghai Tower & 70 & mega słupy do poziomu 35 kondygnacji \\
\hline
\end{tabular}

12 Odkształcenia sprężyste betonu w dużym stopniu zależą od rodzaju zastosowanego kruszywa. Z uwagi na fakt że wraz ze zmianą gęstości objętościowej kruszywa zmienia się również gęstość objętościowa betonu, należy uwzględnić ten parametr betonu przy wyznaczaniu modułu sprężystości. Zastosowany beton o wysokiej wytrzymałości w 1WTC miał moduł Younga o wartości około $48 \mathrm{GPa}$. 


\section{Projekt rozwiązań bezpieczeństwa}

David Childs i jego zespół z pracowni architektonicznej Skidmore, Owings \& Merrill opracowali projekt, który przekracza dotychczasowe standardy bezpieczeństwa, ponieważ dawne zabezpieczenia okazały się niewystarczające w przypadku bliźniaczych wież WTC1 i WTC2. Wyposażenie 1WTC wyznacza nowy standard dla budynków wysokościowych. Wiedząc, jakie były słabe punkty dawnych wież, zespół Childsa zastosował w konstrukcji znacznie mniej stali, a więcej materiałów kompozytowych. Fundament wykonano z betonu, ale z domieszką zwiększającą odporność na wstrząsy (tzw. zielony beton). Podstawa o wysokości $56 \mathrm{~m}$ jest betonową ścianą bez okien zaprojektowaną w celu zaabsorbowania fali uderzeniowej od ewentualnego wybuchu bomby. Podobną rolę pełni szkło w fasadzie pokryte laminatem. Powyżej tej masywnej podstawy wznosi się stalowa konstrukcja ramowa złożona z belek i słupów z połączeniami spawanymi i skręcanymi na śruby. Windy w 1WTC znajdują się w centralnej strukturze trzonu, który jest pionowym betonowym bunkrem. Oprócz tego w windach wykorzystano również cały system MEH (mechaniczny, elektryczny, hydrauliczny) oraz systemy bezpieczeństwa i ratowania życia. Ściany działowe są wzmocnione betonem i wykończone materiałami niepalnymi. Zastosowany beton jest praktycznie ognioodporny, a w klatce schodowej występuje system różnicowania ciśnienia, aby zapobiec przedostawaniu się dymu na schody ewakuacyjne. System wentylacyjny został zabezpieczony specjalnymi filtrami na wypadek ataku terrorystycznego z użyciem substancji chemicznych lub biologicznych. Założono, że ewakuacja budynku, w którym mają pracować tysiące ludzi, musi przebiegać sprawnie, klatki schodowe są szersze o 20\%. Wykonano również specjalną klatkę schodową dla szybkiego reagowania, wykorzystywaną przez ekipy ratownicze, gdy niedostępne są schody ogólnodostępne.

Windy są większe, niż w dawnych wieżach i jest ich aż 73. Oddzielne windy wodoi ognioodporne przewidziano dla strażaków oraz służb porządkowych. Wszystkie drogi ewakuacyjne, np. schody, maja niezależne systemy instalacyjne: wentylacyjny, radiowy i oświetleniowy. Jakość powietrza w budynku kontroluje 3 tysiące czujników. Jeżeli jeden wykryje nadmierną ilość dwutlenku węgla, natychmiast przekazuje sygnał do komputera, który automatycznie tłoczy więcej tlenu do danego pomieszczenia. W przypadku pożaru budynek posiada zbiorniki na wodę o podwójnej pojemności w stosunku do wymagań normowych dla budynków Nowego Jorku. Natomiast tryskacze i przyciski sygnalizujące awarie są chronione betonowymi osłonami.

\section{Projekt rozwiązań ekologicznych}

Wieżowiec One World Trade Center jest jednym z najbardziej ekologicznych biurowców świata, należącym do piątej generacji pod względem zużycia energii [12]. Budynek został nagrodzony złotym certyfikatem LEED $^{13}$, co potwierdza że został zaprojektowany w taki sposób, aby być przyjazny dla środowiska. Zgodnie z wytycznymi LEED ponad 30\% zastosowanych materiałów pochodzi ze źródeł regionalnych, a 25\% z poprzemysłowych

\footnotetext{
${ }^{13}$ LEED - system certyfikacji ekologicznej budynków opracowany przez U.S. Green Building Council. W systemie certyfikacji LEED wyróżnionych jest siedem głównych kategorii. W każdej z nich wydzielono podkategorie, które opisują standardy, jakim powinien odpowiadać certyfikowany budynek oraz wymagania krytyczne, od których zależy zakwalifikowanie budynku do procedury certyfikacyjnej. Wymagania krytyczne to: zrównoważona lokalizacja, efektywne wykorzystanie zasobów wodnych, energia i atmosfera, materiały i zasoby, jak również jakość środowiska wewnętrznego.
} 
materiałów poddanych recyklingowi. Ponadto normy dotyczące różnych szkodliwych substancji występujących w śladowych ilościach w zastosowanych materiałach budowlanych są znacznie wyższe od wymagań stawianych przez amerykańskie prawo. Zastosowany tzw. „zielony beton” [13] odgrywa również ważną rolę w kategorii budownictwa ekologicznego, ponieważ produkcja cementu jest znaczącym źródłem dwutlenku węgla, szkodliwego gazu cieplarnianego. Wytwarzanie tony cementu daje około tony emisji dwutlenku węgla, z czego około połowa pochodzi z paliw kopalnych spalanych w celu ogrzania wapienia, a połowa z kalcynacji wapienia. Ponieważ beton w 1WTC zużywa o $40 \%$ mniej cementu, to powoduje, że projektantom udało się wprowadzić redukcję o około 33000 ton dwutlenku węgla.

Budynek jest częściowo zabezpieczony w dostawę energii poprzez 12 baterii napędzanych wodorem. Generują one moc o wartości 4,8 megawat dla siebie i innych budynków w kompleksie World Trade Center. Oprócz ogniw paliwowych, jest wyposażony w zaawansowaną technologię oszczędzania energii oraz szkło nowej generacji (o większej przejrzystości) i wysokowydajny sprzęt do obniżania zużycia energii. Dodatkowo 1WTC został wyposażony m.in. w system „Day light”, automatycznie sterujący oświetleniem wewnątrz budynku. Jeśli przez okna wpada wystarczająco dużo światła słonecznego, system automatycznie przyciemnia oświetlenie redukując energię. Występuje tutaj również system monitorujący stężenie dwutlenku węgla, dla zapewnienia dobrego samopoczucia i wydajności ludzi pracujących w budynku. Natomiast, gdy stężenie dwutlenku węgla wzrośnie ponad ustalone wcześniej normy, to system automatycznie zacznie dostarczać tam więcej natlenionego powietrza.

Innym ekologicznym rozwiązaniem w budynku 1WTC są zbiorniki magazynujące wodę deszczową, która pomaga ochłodzić budynek i nawadniać okoliczne zieleńce. Woda, w tym wypadku pobierana z rzeki Hudson, służy do wspomagania klimatyzacji budynku. Takie innowacyjne rozwiązania pozwoliły zredukować zużycie wody o około 40 procent więcej niż w typowych ekologicznych budynkach Nowego Jorku

\section{Podsumowanie}

One World Trade Center to główny budynek odbudowanego kompleksu World Trade Center na Dolnym Manhattanie w Nowym Jorku. Wieżowiec 1WTC jest jednym z najnowocześniejszych budynków początku XXI wieku i jest najwyższym budynkiem na półkuli zachodniej oraz szóstym najwyższym na świecie. Ma duże znaczenie ze względu na konstrukcję, symbolikę i przyczynę, dla której został zbudowany. Główny architekt Childs z zespołem pracowni architektonicznej Skidmore, Owings and Merrill zrobili wszystko aby uzyskać wzór samowystarczalności energetycznej, ekologicznej ale przede wszystkim symbol bezpieczeństwa. Wkrótce po zamachu na wieże World Trade Center 11 września 2001 r. w USA ogłoszono koniec epoki wieżowców. Jednak zaprzecza temu omówiony w artykule projekt. Projekt One WTC zasadniczo różni się od projektu bliźniaczych wież World Trade Center. Bardzo trudnym zadaniem technologicznym ze względu na ograniczenia przestrzenne, obejmujące podziemną stację metra, było wykonanie pięciokondygnacyjnej konstrukcji podziemnej. Szczególnie trudna była realizacja słupów przechodzących przez tory stacji kolejowej i poniżej pod nią.

Głównym elementem nośnym bliźniaczych wież były stalowe słupy, natomiast w One World Trade Center występuje hybrydowa konstrukcja z betonu i stali. Kluczem do osiągnięcia jego dużej wytrzymałości jest otoczony stalową ramą trzon wykonany z ultra wytrzymałego betonu i działający jako podstawowe wsparcie budynku, przeciwdziałając grawitacji oraz obciążeniom wiatrem i sejsmicznym. Belki stalowe osadzone w betonowym trzonie wspierają płyty stropowe i umożliwiają uzyskanie rozległych przestrzeni bezsłupowych. 
W trzonie znajdują się dwie połączone ze sobą klatki schodowe oraz specjalnie dedykowane schody pierwszego reagowania umożliwiające ratownikom szybkie wejście do budynku. Zastosowanie betonu o wysokiej wytrzymałości umożliwiło zmniejszenie grubości ścian, uzyskanie maksymalnej powierzchni użytkowej oraz minimalnej wagi zastosowanych materiałów. Zastąpienie 50\% cementu przemysłowymi produktami ubocznymi. które obniżyło ślad węglowy budynku oraz zastosowanie stali pochodzącej w znacznym sopniu z recyklingu przyczyniło się do uzyskania certyfikatu LEED Gold.

Bardzo charakterystycznym i wyróżniającym elementem wieżowca One World Trade Center jest jego unikalna fasada. Jej niesamowity efekt został uzyskany dzięki specjalnie opracowanym taflom szkła, które ma bardzo wysoką wartość współczynnika przenikania U. Zastosowane szkło jest transparentne i ma odblaskową lustrzaną powłokę, która tworzy stale zmieniający się kalejdoskop. Dzięki zastosowanemu przeszkleniu o wysokości całej kondygnacji uzyskano efekt maksymalnego przenikania naturalnego światła do wnętrza budynku.

Podsumowując należy podkreślić, że puste miejsce po dawnych wieżach World Trade Center 1 i 2 przez wiele lat przypominające mieszkańcom Nowego Jorku i całemu światu o strasznej tragedii, nigdy nie doczekało się zupełnego zamknięcia. Dzięki realizacji tego odważnego i synergicznego wykorzystania dostępnych technologii osiągnięto cel mimo znacznego kosztu (3,9 mld dolarów), wykorzystano najnowocześniejsze metody maksymalizacji wydajności energetycznej budynku, minimalizacji odpadów i zanieczyszczeń, oszczędności wody, polepszenia jakości powietrza i redukcję wpływu zabudowy. Ponadto zastosowanie najnowocześniejszej konstrukcji hybrydowej wykracza w znacznym stopniu ponad standardy dotychczas budowanych wieżowców na świecie.

\section{Literatura}

[1] Kumorek M. Analiza Rozwoju Budownictwa Wysokiego. Przestrzeń i Forma, 2014, s. 91-134.

[2] www.wsp-pb.com/en/High-Rise/High-Rise-Insight/World-Trade-Center.

[3] Lewis S. A. Raising The 1 World Trade Center. Wire Rope Exchange, 2013, s. 16-20.

[4] One World Trade Center / SOM. ArchDaily, 14 September 2016.

[5] VIRACON - Product Guide.

[6] Price B. One World Trade Center, New York and The Shard, London. High Rise Structures in Construction, 2012, s. 1-5.

[7] Rahimian A., Eilon Y. The Rise of One World Trade Center. Structure, 2012, s. 22-24.

[8] Sev A., Özgen A. Space Efficiency in High Rise Office Buildings. METU JFA, 2009, s. 69-89.

[9] Lewis K., Holt N. Case Study: One World Trade Center, New York. CTBUCH Journal, Issue III, 2011.

[10] Kurdowski W., Szeląg H. Korozja betonu wywołana opóźnionym powstaniem ettringitu. XXV Konferencja Naukowo-Techniczna „Awarie Budowlane”, 2011, s. 1119-1126.

[11] Dahlin T., Yngvesson M. Construction Methodology of Tubed Mega Frame Structures in High-rise Buildings, Master Thesis in Concrete Structures, Royal Institute of Technology, Stockholm, Sweden, 2014, s. 1-132.

[12] Oldfield P., Trabucco D., Wood A. Five Energy Generations of Tall Buildings: A Historical Analysis of Energy Consumption in High Rise Buildings. CTBUCH Research Paper, $8^{\text {th }}$ World Congress, Dubaj, ZEA, s. 1-11.

[13] Pietrzak A. Proekologiczne technologie w budownictwie na przykładzie ,,zielonego betonu”. Budownictwo o zoptymalizowanym potencjale energetycznym 1(13) (2014) 86-93. 


\title{
Skyscraper One World Trade Center in New York City - the modern green office building with a hybrid structure
}

\author{
Hanna Golasz-Szołomicka ${ }^{1}$, Jerzy Szołomicki² \\ ${ }^{1}$ Department of History of Architecture, Art and Technology, Faculty of Architecture, \\ Wrocław University of Science and Technology, e-mail: hanna.golasz-szolomicka@pwr.edu.pl \\ ${ }^{2}$ Department of Building Physics and Computer Design Methods, Faculty of Civil Engineering, \\ Wroctaw University of Science and Technology, e-mail: jerzy.szolomicki@pwr.edu.pl
}

\begin{abstract}
This article presents elements of architectural and structural analysis of the safest and most environmentally-friendly skyscraper of One World Trade Center, which is the new symbol of New York located in Lower Manhattan. This building apart from the obvious symbolic dimension of the future and hope is a showcase of the most advanced technology. Because of this, the 1WTC design exceeds New York's building standards and sets new standards for new high-rise buildings. This skyscraper is an octahedron based on a rectangular base, resembling a natural crystal. As the height increases, its edges are chamfered, significantly reducing the impact of the wind, which is a major determinant in the design of high-rise buildings in New York. The article presents design solutions from the point of view of innovative architecture, construction, urban design, security and sustainable building. The design team used state-of-the-art methods to maximize the efficiency of the building, minimize waste and pollution, save water, improve air quality and reduce the impact of other buildings. One World Trade Center received the LEED Gold Certificate as an Energy-Efficient Building.
\end{abstract}

Keywords: One World Trade Center; high buildings; hybrid construction; sustainable building. 